The provisional nature of science $\mid 82$

CAROLINA SOTÉRIO ${ }^{1}$

\title{
The provisional nature of science evidenced in times of pandemic ${ }^{2}$
}

Trust in science has been problematic over the years. The roots of the problem, in turn, are deep. For a long time, it was believed that the primary obstacle would center on the need for greater provision of scientific information to the nonspecialist audience. However, this is a deficit view of the public "understanding" of science and technology, which disregards the associated historical, social and political contexts (Lewenstein 2003). The Digital Age has made this issue even more evident, as scientific information is everyday more rapidly accessible online.

During the Covid-19 pandemic, global efforts mobilized to share information about this unprecedented scenario, bringing science to the spotlight. Consequently, the population followed every new discovery on-demand, from public policy to vaccine development challenges. This panorama puts the science trust in check again: social media gave voice not only to scientists, but also to any user to express their frustrations on this provisional moment, highlighting what was already known by academics: knowledge is constantly changing.

Public decisions on Covid-19 taken by the World Health Organization (WHO) evolved alongside scientific evidence and inspired several governments to do the same, so, for each new published research, the institutions had to change their previous strategies. Even though "going back" on decisions can represent an advance in evidence-based policies, the expression has been pejoratively used on the Internet to discredit science. With this in mind, this manuscript contributes to

\footnotetext{
${ }^{1}$ Chemist, PhD student in Public Communication of Science and Technology (University of São Paulo) and Specialist in Science Journalism (State University of Campinas), Brazil.

2 This article was originally published in http://www.alternautas.net/blog/2021/6/16/theprovisional-nature-of-science-evidenced-in-times-of-pandemic
} 
the studies about the "public trust in science" in risk communication, with emphasis on the discursive relations present in the public response to the evidence-based policies about Covid-19, illustrating the presence of a deterministic view of science. The investigation occurred through the search for the "voltou atrás" ("went back") keyword in Portuguese on Twitter. The Discourse Analysis from the French School was used to analyze the tweets, registering a frame of this particular moment from the Brazilian perspective.

\section{A brief historical-philosophical overview}

Science has not always been the same as it is known today. A range of events and contributions over time demonstrate how a scenario of constant change has always been present in its development. It is worth mentioning that different cultures significantly contributed to the construction of knowledge, such as the mathematics studied by the Arabs, the wisdom about natural products dominated by the Brazilian indigenous peoples or even the paper fabrication by the Chinese. However, specific historical and political factors contributed to the generalization of a philosophy that established the current models, vocabularies and techniques (Chaui 2000).

Looking back in the past, mythology narratives about the gods tried to answer questions that plagued the human mind, including the origin of the world. The ascendancy of things, people and qualities based on mythological figures revealed the idea of genealogy and, in that context, proposed an explanation for what was known. It was the pre-Socratic philosophers who started to present explanations that were not based on the supernatural, among them Thales of Miletus (624-558 $\mathrm{BC})$, who bet on a world formed from water, and Leucipo (500-430 BC) and Democritus (460-370 BC) with atomic theory. Aristotle (384-322 BC), in turn, was a pioneer in declaring that observation and logical reasoning should be combined in the study of the natural world, elaborating the oldest systematic treatise on the nature of scientific research in the West and defending logic as an instrument of knowledge (Chaui 2000; Rosa 2012; Andersen and Hepburn 2020).

The medieval period was influenced by these contributions (Scholastic Philosophy, VIII-XIV century) and, thus, the concept of dispute arose: a form to expose philosophical ideas through the presentation of a thesis to be refuted or 
The provisional nature of science $\mid 84$

defended with arguments based on recognized authorities (whether the bible, religious leaders or the philosophical ideas themselves), revealing the principle of authority. In general, Philosophy covered periods such as the Renaissance (XIV$\mathrm{XVI}$ ), in which theory and practice were fostered with maritime discoveries, also allowing the development of a great critical social sense; Modern Philosophy (XVII-XVIII), which evidenced classical rationalism; and the Enlightenment, supported by the powers of reason. In the XVI-XVIII period the Scientific Revolution was established, representing both an advance in the knowledge of certain areas and a reflection on the method by which it was obtained (Chaui 2000; Andersen and Hepburn 2020). At this time, figures such as Newton, Copernicus and Lavoisier made contributions so significant that they established paradigms, that is, model solutions widely accepted by a community (Kuhn 1998). The Copernican Revolution, for example, overthrew the prevailing idea of a geocentric planetary system by proving mathematically the existence of a heliocentric system. This particular event revolutionized the plurality of areas and thoughts from astronomy to religion, contributing to scientific progress (Idem 1985).

All this movement involved science for commercial purposes, as it happened in the Industrial Revolution (1760-1840), and culminated in the first journalistic coverage of science by means of its universal expositions (Moraes and Carneiro 2018; Sanjad 2017). These, at first, praised the scientific wonders without a deep consideration for the social and environmental impacts. Subsequently, episodes such as the discovery of the dichloro-diphenyl-trichloroethane (DDT) pesticide side effects broadened society's critical view of science and boosted movements like the environmentalist (Rensberger 2009). In this sense, $20^{\text {th }}$ century Philosophy questioned the validity of methods, results, conclusions and scientific limitations (Chaui 2000).

Even the concept of "scientific" is a longstanding discussion. For philosopher Karl Popper, every scientific idea should be subjected to a test to refute it (instead of confirming it), a principle he named as falsifiability. Thereby, science would approach the deductive method, in which "systems of theories are subjected to tests, deducing statements of less universality" (Popper 1959, 49). Thus, science would be composed of theories from tests that failed to refute them, proving quality. However, factors such as the probability of events, the existence of 
theoretical entities and other non-falsifiable principles revealed problems with Popper's principle (Ladyman 2002).

For example, in the scope of historical sciences, it would be unlikely to carry out controlled experiments that reproduce conditions such as the origin of the universe or Planet Earth, in order to attest or discard hypotheses that would explain, among other things, the Big Bang and the dinosaurs' extinction. In these cases, the investigations start from a set of hypotheses that search for evidence capable of pointing, in the light of knowledge, the most probable explanations, bringing to light the methodological differences between some areas that prevent the establishment of a strictly unique protocol for all of them (Cleland 2001).

Modern science then emerges from a moment when new senses appear, and a series of episodes help to break with the deterministic - a concept in which some scientific statements would be immutable - and mechanistic view (Pêcheux and Fichant apud Martins 2009). However, the contemporary discourse in the communication of science to the public often seems to have the opposite effect, attributing decisive characteristics to science content, "as a sorting activity between true and false statements" (Pêcheux 1995, 197). Therefore, an image of science has been produced which is synonymous with absolute truths and which opposes, imaginary, what would be false.

Recently, discussion is set on a "post-truth" scenario, defined as "relating to or denoting circumstances in which objective facts are less influential in shaping public opinion than appeals to emotion and personal belief" by the Oxford Dictionaries (2016), which also nominated it the "Word of The Year" in 2016. This eclipsing of truths also mobilizes a complex philosophical discussion on the "truth" understanding itself (McIntyre 2018). In addition to the theory of truth, it is hereupon important to also investigate the conditions in which "post-truths" are disseminated.

Several events are related to the term's popularization, especially in politics. A direct connection is currently established between the word and episodes such as Donald Trump's election in the United States and the Brexit vote for the United Kingdom to withdraw from the European Union. In these cases, lots of subverted truths were disseminated through social media and influenced public decisions. 
The provisional nature of science $\mid 86$

However, these events do not originate from "post-truth" per se, but rather reflect its results (McIntyre 2018).

Under this umbrella is "fake news" which can be understood as fabricated information in a deliberately false way. The activity was not necessarily born with the Internet, but social media has been the main stage of its spread (Lazer et al. 2018; McIntyre 2018). The strategy was employed in 2018 during Bolsonaro's presidential election in Brazil in order to defeat the opposition. The campaign was marked by attacks on journalists, political candidates and defense of conservatism, all massively propagated through WhatsApp and Facebook (Almeida 2019). A research revealed that $89.7 \%$ of Bolsonaro voters believed in "fake news" (AVAAZ and IDEIA Big Data 2018). Indeed, in the midst of so much information available online, the filter between facts and what is deliberately false often depends on the Internet user (McIntyre 2018).

Science is in the middle of this arena as well, especially in an unprecedented pandemic scenario. With the advancement of technology, the refutation of hypotheses has been occurring at an accelerated pace, mainly due to the demand for effective treatments, data monitoring and information sharing.

\section{Covid-19 provisional scenario}

The pandemic scenario is evolving rapidly. The first officially identified patient with the disease occurred in Wuhan (China) on December 31 $1^{\text {st }}, 2019$ (Huang et al. 2020). On February $26^{\text {th }}, 2020$, the Ministry of Health officially communicated the first case of Covid-19 in Brazilian territory (Brazil 2020). After 48 hours, researchers at the University of São Paulo, in partnership with the University of Oxford, had already sequenced the genome of the new Coronavirus and released the data internationally, a record time compared with the world performance (Girardi 2020).

On March $16^{\text {th }}$, researchers at Imperial College London published a statistical model on the university's website with predictions about the disease in some countries, highlighting the United States and Great Britain. The estimate of deaths in a scenario without mitigation measures was catastrophic: 2.2 million and 510,000 , respectively (Ferguson et al. 2020). On March 26 $6^{\text {th }}$, the data were 
updated in the face of changing scenarios, including Brazil: for a population of $212,559,409$ inhabitants, the worst scenario (without mitigation measures) would have 1,152,283 deaths; the best (with early suppression), 44,212 (Walker et al. 2020).

The constant information updating also occurred in the search for treatments and vaccines, as the need for rapid development has significantly changed the usual scenario: while other vaccines can take decades to develop, Pfizer and BioNTech pharmaceuticals had received the first vaccine approval in December, after only 10 months $^{3}$. All this effort counted on previous knowledge and international cooperation across financing systems, clinical trials, infrastructure, public policy, etc. (Lurie et al. 2020; BBC 2020). Chloroquine (antimalarial) and its derivative (hydroxychloroquine) were hypotheses endorsed in political speeches, particularly by presidents Donald Trump and Jair Bolsonaro, but without promising results (Desideri 2020). A May $22^{\text {nd }}$ article in The Lancet, a prestigious journal, published a survey of 96,032 patients and concluded that, in addition to not showing significant results against the disease, these drugs increased the risk of death. Twelve days later, the study was criticized for data problems (The Lancet Editors 2020).

This situation reveals a demand for results and information that happen at different times: the time of science and the time of science journalism. As we observe researchers studying this unprecedented scenario in an accelerated way, we see communication professionals strive to disseminate the information urgently. And in this scenario circulates a discourse which "is not a sum of speeches: science plus journalism equals public communication of science and technology $(\mathrm{S}+\mathrm{J}=$ PCST). It is a specific articulation with particular effects, which are produced by the injunction to its mode of circulation" (Orlandi 2001, 22-23).

\footnotetext{
${ }^{3}$ Russia registered the first vaccine to fight Covid-19, Sputnik V, in August 2021. However, clinical trials were incomplete at that time.
} 
It is worth remembering that, in the current social formation guided by neoliberalism policy ${ }^{4}$ (Cano 2012), there is great demand for immediate solutions and productivity, which is also reflected in the reality of the pandemic. The socalled "Information Society", which emerged to name the post-industrial world and a paradigm shift, revealed technical, economic, cultural, legal, psychological and philosophical challenges in its construction (Werthein 2000). This pace of ondemand information, in turn, reveals numerous associated problems that are reflected in the coverage of the current pandemic. As noted, the current scenario of uncertainties has even contributed to a lack of rigor in the review of certain studies.

All this lack of information has caused anguish in part of the population that questions the Internet about issues such when the disease will peak, when the pandemic will end, the delay in producing a vaccine and even the validity of direct attacks on the credibility of scientists and communicators. The biologist Atila Iamarino, an icon in the dissemination of accurate pandemic information in Brazil, received harsh criticism when updating the Imperial College London data in his videos, which reached record viewing, despite his warning that these were predictions (Iamarino 2020a; 2020b; 2020c). Due to the growing attack on the scientific disseminator, the hashtag \#ObrigadoAtila (\#ThankYouAtila) was mobilized on Twitter on August $1^{\text {st }}$ as a social defense, culminating in the first position of the Trending Topics Brazil (Trendinalia 2020).

Considering these events and the importance of social media in the dissemination of information on Covid-19, the discourses produced on the subject on Twitter was analyzed due a series of social engagement around the topic on the platform, as follows.

\footnotetext{
${ }^{4}$ According to Cano (2012), the policy of neoliberalism comprises a "modern" way of arguing in favor of reducing State participation in the market economy and increasing deregulation (such as labor, social security, etc.) by means of privatization policies and structural reforms of a liberalizing nature. Endorsed mainly by the technological advances of the III Industrial Revolution, it reinforces the capitalist nature of adopting faster and less costly solutions, leading to precarious employment relationships and the weakening of social policies, among other perverse consequences. Here, I use the term to refer to the current neoliberalist discourse, especially present in Brazil.
} 


\section{Analyzing Tweets}

The search started with the assumption of "provisional science", whose selection of comments on Twitter took place through the keyword "voltou atrás" ("went back" and its derivatives, in English), inserted in the website search field. The statement choice came after a qualitative observation of similar terms recurrence in the social media, mainly after the release of reports from the Imperial College. The subject gained even more attention when political demonstrations were dedicated to attacking public figures who communicated accurate information about the pandemic, supported by the "change in attitude" in the face of the new data. "Backing out" has become commonplace in an unprecedented situation, as new information about Covid-19 emerges every day. As such, the search was limited to comments made in the first half of 2020, the initial period of the pandemic, in which many positions have changed due to the lack of knowledge about it.

Twitter was chosen because it is the stage for great discussions, in addition to allowing the use of hashtags, search engines often linked to organized movements, whose mentions in large quantities gain prominence in the network itself, a way to rank the most commented subjects by location. Furthermore, the site favors direct interaction between anonymous users ${ }^{5}$, public figures and organizations, facilitating almost instantaneous content monitoring performed by individual users. Twitter, which has about 340 million active users worldwide, is the sixth most accessed platform in Brazil (DataReportal 2020).

Since the social media is dynamic and updates its pages frequently, the comments presented here do not belong to a single thread, but rather to several conversations that occurred in parallel on the website, connected by the keyword. (Figure 1).

\footnotetext{
5 "Anonymous" here means a public profile not verified by Twitter, that is, the common user (who is not a public figure or represents an organization).
} 
Figure 1. Set of comments transcribed from Twitter about the new Coronavirus and the provisional nature of science (preserved anonymity).

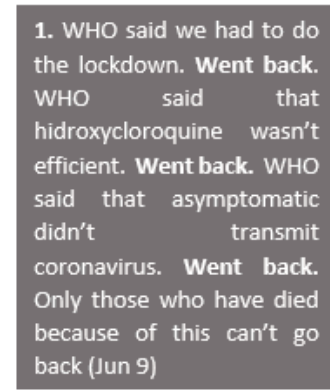

5. Isolation has no scientific proof. WHO has already gone back on several things said. And now it says that asymptomatic and preasymptomatic patients have a low rate of transmission. Count how many Brazilians there are in Brazil and the death toll, do you know the fraction and proportion? (Jun 11)

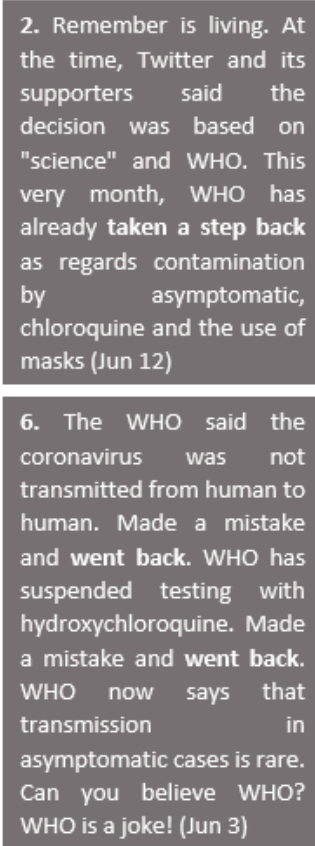

4. You took too long, there was no time. WHO has already taken a step backwards, it has retreated. Now record another video with him to say that the WHO said yes but now "un"said what had said. But that tomorrow you can talk again without wanting to "un"say what "un"said today. Okay? (Jun 9)

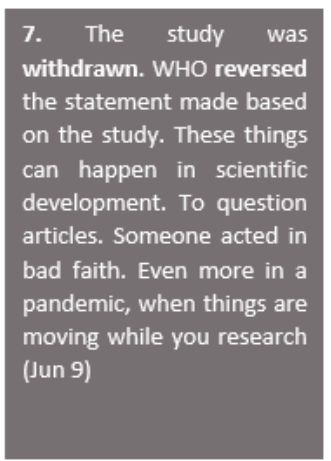

8. I understood. WHO is not to blame for this. The article was published in one of the best journals in the world, with the greatest impact factor. The publication was revised and WHO backed down on the suggestion. In science this happens, we are understanding the disease, there are no definitive conclusions (Jun 9)

These comment authors do not have verified profiles. They are sometimes conversations (in response to profiles that are also anonymous), public posts that dialogue with news or are not directed at a particular profile. Of these, some reject the change in positions (1-6) while others try to contextualize the provisional nature of science (7-8).

Most comments coincide with a specific date: WHO's June $9^{\text {th }}$ statement on the misconception that asymptomatic transmission of the virus would be rare. That same month also marked the retraction of The Lancet article on chloroquine and hydroxychloroquine and the emergence of scientific evidence to support the widespread use of masks by healthy people, both previously not recommended by the institution (WHO 2020).

When analyzing the comments in greater depth, we find that the possible meanings of these comments exceed the 280 characters of Twitter, and refer to the interdiscourse, that is, "something speaks before, elsewhere and independently" (Pêcheux 1995, 99) and that returns on the basis of the sayable. It 
is "the set of sayings already said and forgotten that determine what we say, sustaining the very possibility of saying" (Orlandi 2008, 59). Thus, the discourses of social networks dialogue, in a certain instance, contains a vision of science that has already been established. Therefore, "The meaning of a word, of an expression, of a proposition, etc., does not 'exist in itself' (that is, in its transparent relationship with the literalness of the signifier), but, on the contrary, it is determined by the ideological positions that are at stake in the socio-historical process in which words, expressions and propositions are produced (that is, reproduced)" (Pêcheux 1995, 160). This sense, according to the author, is present in the metaphor relations, which can be identified by the effects of substitution, paraphrases, synonyms.

Thus, on the one hand, the comments reveal an antonym relation between WHO and science, which denies the organization's institutional position. Observing comment 2 "this very month WHO has taken a step back as regards contamination by asymptomatic people, chloroquine and the use of masks". Firstly: In such a short time, WHO changed its position regarding contamination by asymptomatic, chloroquine and the use of masks. Secondly: WHO is not sure! And, thirdly: WHO is not science! This way of denying resumes, by referring to interdiscourse, the deterministic view of a science that does not allow itself to "go back": WHO is not sure (A); Science is sure $(B)$; Therefore, WHO cannot be science $(A \neq B)$. To say, then, that WHO does not base itself on science in its decisions - due to the change of positions - is to place science on a level of absolute truth, which corroborates with a deterministic view still present in contemporary times (Martins 2009). This memory of unchanging science is present in these discourses produced in the current social and historical conditions surrounding science in the face of the Covid-19 pandemic.

Still, the comment calls for fatality. The mention of the number of deaths was used as the effects of a "not-science". Observing the premises of comment 1 "WHO (...) went back. Only those who have died because of this cannot go back", relations also apply: WHO made a decision $(\mathrm{A} \Rightarrow \mathrm{B})$; The decision caused deaths $(\mathrm{B} \Rightarrow \mathrm{C})$; WHO caused deaths $(\mathrm{A} \Rightarrow \mathrm{C})$. In these speeches, "going back" implies being wrong and, consequently, assuming dire consequences. 
The provisional nature of science $\mid 92$

Other times, the institution and science are treated as synonymous. Observing comment 6 "WHO said that the coronavirus was not transmitted from human to human. They made a mistake and went back. (...) Can you believe WHO? WHO is a joke!", In the criticism of WHO there is also an implicit criticism of science, once the organization's actions were based on scientific evidence. So, when new studies overturned previous hypotheses, which proved to be common in the face of an unknown disease, the WHO also reversed, in order to maintain a position consistent with the scientific literature. In this line of reasoning, scientific provisionality is assumed, but this is placed as a factor of discredit. Rephrasing it: "can you believe in science? Science is a joke!".

It cannot be claimed that the speeches are not "scientific" to some extent. Even in positions that question trust in WHO and, subsequently, in science, there is a foundation in studies, organizations, concepts, among others, as arguments. However, the identified deterministic view of science contributes to the denial of its provisional character, which is mistaken and does not support the claims that "going back" is unscientific. On the contrary, provisionality supports scientific progress in the face of new research.

The numerical predictions that have been made are predictions. Estimating values in a scenario never before seen is an exercise in uncertainty, but one that becomes necessary to guide competent institutions in their decisions. However, it is essential to understand that the associated political debate directly affects the pandemic data, since measures such as social distancing have been shown to be effective against the disease transmission in a scenario without a vaccine (Nouvellet et al. 2020); notably, these measures depend on public policies to be effectively implemented. In Brazil, the president called Covid-19 a "little flu" during an official announcement, an attitude that minimized WHO's social distancing recommendation. According to McIntyre (2018), science denialism in this "post-truth" arena can lead to perverse consequences: when a private individual denies a fact, he faces the problem; but when a leader does, the results are catastrophic.

Another aspect that correlates with the constantly changing scenarios is the fact that the race for knowledge sharing has boosted access to studies not yet peerreviewed (preprints). Although these promote a debate, visibility and 
dissemination of scientific content at first hand, there are concerns that must be considered, since the information review process is not complete (Spinak 2016). However, even in the case of studies that have been screened by specialists, about $27 \%$ of the errors that cause papers to be rejected from scientific journals are related to problematic data, according to a study conducted with publications in the field of chemistry and materials science (Coudert 2019).

Yet, just as the way of producing new knowledge has evolved over time, knowledge itself has also evolved. Science tends to bring many more questions than answers and is far from proposing definitive solutions, building on previous hypotheses to reach new perspectives. Scientific knowledge is put in check all the time and the refutation of hypotheses is part of its development process. However, even the scientific method has its limitations and investigations of different natures may require different methodologies. Most experimental scientists focus on one main hypothesis and on avoiding false refutations or corroborations in relation to the factors that may influence the results obtained (Cleland 2001).

Finally, it is necessary to consider language in its functioning in relation to exteriority, since it is not only at the base of all knowledge production, but also in the mediation of our relationship with the world, with objects and with others. "Language is the fabric of memory, that is, its essential mode of existence" (Courtine 1994, 5). This consideration makes it possible to observe the way in which scientific discourse is produced in our society.

\section{Final considerations}

The information demand in the Covid-19 pandemic is growing and is facilitated by the Digital Age. Popular frustration with the constant scenarios' change and the inaccuracy about certain preventive measures or possible treatments is a debate topic on social media, but also historical in the course of a new knowledge development. In this sense, this manuscript intended to understand the public response to the evidence-based policies on Covid-19 through the linguistic relations present in online speeches.

The study's findings evidenced a deterministic view of science present in different discourses formulated by nonexperts on Twitter, specifically commenting on 
WHO's position. Initially, "science" and "WHO" were mentioned in the opposite sense (antonym relation): according to a science that never goes back, the position of WHO going back was unscientific. In this case, many speeches put the fatality of the disease as one of the effects of this non-scientific positioning. In another sense, the words were used as synonyms: if WHO was reversing its decisions, which would be scientific, then science would not be reliable. Still, there were users who tried to respond to these comments, placing the provisional nature of science as necessary for scientific progress.

Among the reasons that favor the appearance of such comments is the contemporary scenario of "post-truths", in which deliberately false information is disseminated, mainly in the political sphere. Indeed, the comments used "subverted truths" when quoting studies to discredit science. Evidently, the pressure for answers affected the research peer-review process and must be considered for a scientific exercise aware of its social implications.

Also, this study was limited to Twitter and situated in Brazil, but other contributions can be made on different platforms, languages and perspectives, in order to verify how these discourse relations are maintained or altered in other contexts, since the communication about the Covid-19 was carried out differently around the world, and historical, social, cultural and political factors are intrinsically connected to the study problem. The science trust subject is complex and must be studied considering the conditions in which the senses are formulated and circulate.

\section{References}

Almeida, Ronaldo de. 2019. "Bolsonaro Presidente: Conservadorismo, Evangelismo E a Crise Brasileira." Novos Estudos CEBRAP 38 (1): 185-213. https://doi.org/10.25091/s01013300201900010010.

Andersen, Hanne, and Brian Hepburn. 2020. "Scientific Method." Stanford Encyclopedia of Philosophy. 2020. Accessed April 20, 2020. https://plato.stanford.edu/archives/win2020/entries/scientific-method/. 
AVAAZ, and IDEIA Big Data. 2018. "Eleições e Fake News." Accessed January 10, 2021. https://avaaz.org/act/media.php?press_id=918.

BBC, British Broadcasting Corporation. 2020. "Vacina Contra Covid-19: Reino Unido é $1^{\circ}$ País a Aprovar Imunizante Da Pfizer e Pode Iniciar Aplicação Em Uma Semana." Accessed December 20, 2020. https:/www.bbc.com/portuguese/internacional-55156721.

Brazil. 2020. "Brasil Confirma Primeiro Caso de Novo Coronavírus." Accessed May 01, 2020. https://www.gov.br/pt-br/noticias/saude-e-vigilanciasanitaria/2020/02/brasil-confirma-primeiro-caso-do-novo-coronavirus.

Cano, Wilson. 2012. Introdução à Economia: Uma Abordagem Crítica. 3rd ed. São Paulo: Editora Unesp.

Chaui, Marilena. 2000. Convite à Filosofia. São Paulo: Ática.

Cleland, Carol E. 2001. "Historical Science, Experimental Science, and the Scientific Method.” Geology 29 (11): 987-90. https://doi.org/10.1130/00917613(2001)029<0987:HSESAT>2.0.CO;2.

Coudert, François X. 2019. "Correcting the Scientific Record: Retraction Practices in Chemistry and Materials Science." Chemistry of Materials 31 (10): 3593-98. https://doi.org/10.1021/acs.chemmater.9b00897.

Courtine, Jean-Jacques. 1994. "Le Tissu de La Mémoire : Quelques Perspectives de Travail Historique Dans Les Sciences Du Langage.” Langages 28 (114): 5-12. https://doi.org/10.3406/lgge.1994.1673.

DataReportal. 2020. “Digital Brazil: 2020.” Accessed August 25, 2020. https://datareportal.com/reports/digital-2020-brazil .

Desideri, Leonardo. 2020. "Por Que a Cloroquina Virou Discussão Política No Brasil; Confira Argumentos Dos 2 Lados.” Gazeta Do Povo. Accessed October 08, 2020. https://www.gazetadopovo.com.br/republica/por-que-a-cloroquinavirou-discussao-politica-no-brasil/. 
The provisional nature of science $\mid 96$

Girardi, Giovana. 2020. "Pesquisadores Brasileiros Sequenciam Genoma Do Coronavírus Identificado No País." Estadão. Accessed May 01, 2020. https://saude.estadao.com.br/noticias/geral,pesquisadores-brasileirossequenciam-genoma-do-coronavirus-identificado-no-pais, 70003214162.

Huang, Chaolin, Yeming Wang, Xingwang Li, Lili Ren, Jianping Zhao, Yi Hu, Li Zhang, et al. 2020. "Clinical Features of Patients Infected with 2019 Novel Coronavirus in Wuhan, China." The Lancet 395 (10223): 497-506. https://doi.org/10.1016/S0140-6736(20)30183-5.

Iamarino, Atila. 2020a. "Por Que é Importante Ficar Em Casa? \#FiqueEmCasa." $\begin{array}{llll}\text { YouTube. Accessed } & \text { April } & 2020 .\end{array}$ https://www.youtube.com/watch?v=HXmt0j1gtDU.

—. 2020b. "Live 20/03 - O Que o Brasil Precisa Fazer Nos Próximos Dias \#FiqueEmCasa." $\quad$ YouTube. Accessed April 20, 2020. https://www.youtube.com/watch?v=zF2pXXJIAGM .

—. 2020c. "A Situação Do Brasil Pode Ser Melhor." YouTube. Accessed April 20, 2020. https://www.youtube.com/watch?v=2DAIe1SILMo.

Kuhn, Thomas S. 1985. The Copernican Revolution: Planetary Astronomy in the Development of Western Thought. 2nd ed. Cambridge \& London: Harvard University Press.

—. 1998. A Estrutura Das Revoluções Cientificas. 5th ed. São Paulo: Perspectivas.

Ladyman, James. 2002. Understanding Philosophy of Science. Routledge. London \& New York: Routledge (Taylor \& Francis Group).

Lazer, David M. J., Matthew A. Baum, Yochai Benkler, Adam J. Berinsky, Kelly M. Greenhill, Filippo Menczer, Miriam J. Metzger, et al. 2018. "The Science of Fake News." Science 359 (6380): 1094-96. https://doi.org/10.1126/science.aao2998. 
Lewenstein, Bruce V. 2003. "Models of Public Communication of Science and Technology." ECommons. Ithaca. Accessed April 20, 2020. https://creativecommons.org/licenses/by-nc-nd/4.0/.

Lurie, Nicole, Melanie Saville, Richard Hatchett, and Jane Halton. 2020. "Developing Covid-19 Vaccines at Pandemic Speed." New England Journal of Medicine 382 (21): 1969-73.

Martins, Marci F. 2009. “O Discurso Da Ciência Na Contemporaneidade: 'Nada Existe a Menos Que Observemos." Rua 15 (2): 99-115. https://doi.org/10.20396/rua.v15i2.8638861.

McIntyre, Lee. 2018. Post-Truth. Cambridge \& London: The MIT Press.

Moraes, Eduardo C., and Erica Mariosa Moreira Carneiro. 2018. "A Evolução Do Jornalismo Na Divulgação Científica." ComCiência, 2018. https://www.comciencia.br/evolucao-do-jornalismo-na-divulgacao-cientifica/.

Ferguson, Neil M., Daniel Laydon, Gemma Nedjati-Gilani, Natsuko Imai, Kylie Ainslie, Marc Baguelin, Sangeeta Bhatia, et al. 2020. "Report 9: Impact of NinPharmaceutical Interventions (NPIs) to Reduce COVID-19 Mortality and Healthcare Demand." Imperial College COVID-19 Response Team. London. https://doi.org/https://doi.org/10.25561/77482.

Nouvellet, Pierre, Sangeeta Bhatia, and Anne Cori. 2020. "Report 26: Reduction in Mobility and COVID-19 Transmission." Imperial College London, no. June: 1-94. https://doi.org/https://doi.org/10.25561/79643.

Orlandi, Eni P. 2001. "Divulgação Científica e Efeito Leitor: Uma Política Social Urbana." In Produção e Circulação Do Conhecimento: Estado, Midia, Sociedade, 21-30. Campinas: Pontes Editores.

- 2008. Discurso e Texto: Formulação e circulação dos sentidos. 3rd ed. Campinas: Pontes Editores.

Oxford Dictionaries. 2016. "Post-Truth.” Accessed January 10, 2021. https://languages.oup.com/word-of-the-year/. 
The provisional nature of science $\mid 98$

Pêcheux, Michel. 1995. Semântica e Discurso: Uma Crítica à Afirmação Do Óbvio. 2nd ed. Campinas: Editora da Universidade Estadual de Campinas.

Pêcheux, Michel, and Michel Fichant. 1971. Sobre a história das ciências. São Paulo: Estampa apud Martins, Marci F. 2009. "O Discurso Da Ciência Na Contemporaneidade: 'Nada Existe a Menos Que Observemos." Rua 15 (2): 99115. https://doi.org/10.20396/rua.v15i2.8638861

Popper, Karl R. 1959. A Lógica Da Pesquisa Científica. São Paulo: Editora da Universidade de São Paulo \& Editora Cultrix.

Rensberger, Boyce. 2009. "Science Journalism: Too Close for Comfort." Nature 459 (7250): 1055-56. https://doi.org/10.1038/4591055a.

Rosa, Carlos A. P. 2012. História Da Ciência Renascimento Científico História Da Ciência. 2nd ed. Brasília: Fundação Alexandre Gusmão.

Sanjad, Nelson. 2017. "Exposições Internacionais: Uma Abordagem Historiográfica a Partir Da América Latina." História, Ciências, Saúde Manguinhos $24 \quad$ (3): $\quad 785-826 . \quad$ https://doi.org/10.1590/s010459702017000300013.

Spinak, Ernesto. 2016. “O Que é Este Tema Dos Preprints?" Scielo Em Perspectiva. Accessed April 10, 2020. https://blog.scielo.org/blog/2016/11/22/oque-e-este-tema-dos-preprints/.

The Lancet Editors. 2020. "Expression of Concern: Hydroxychloroquine or Chloroquine with or without a Macrolide for Treatment of COVID-19: A Multinational Registry Analysis." The Lancet 395 (10240): e102. https://doi.org/10.1016/S0140-6736(20)31290-3.

Trendinalia. 2020. "Trendinalia Brasil." Accessed August 25, 2020. http://www.trendinalia.com/twitter-trending-topics/brasil/brasil-200801.html.

Walker, Patrick G. T., Charles Whittaker, Oliver Watson, Marc Baguelin, Kylie E. C. Ainslie, Sangeeta Bhatia, Adhiratha Boonyasiri, et al. 2020. "The Global Impact of COVID-19 and Strategies for Mitigation and Suppression." Imperial 
College COVID-19 Response Team, no. March: 1-19. https://doi.org/https://doi.org/10.25561/77735.

Werthein, Jorge. 2000. "A Sociedade Da Informação e Seus Desafios." Ciência Da Informação 29 (2): 71-77. https://doi.org/10.1590/s010019652000000200009.

WHO, World Health Organization. 2020. "Rolling Updates on Coronavirus Disease (COVID-19)." Accessed August 25, 2020. https://www.who.int/emergencies/diseases/novel-coronavirus-2019/events-asthey-happen. 